\title{
Risk factors of breast cancer and knowledge about the disease: an integrative revision of Latin American studies
}

\author{
Fatores de risco do câncer de mama e o conhecimento \\ sobre a doença: revisão integrativa de estudos Latino Americanos
}

Aline Ferreira de Araújo Jerônimo ${ }^{1}$

Ângela Gabrielly Quirino Freitas ${ }^{1}$

Mathias Weller ${ }^{1}$

Programa de PósGraduação em Saúde Pública, Universidade Estadual da Paraíba. R. Baraúnas 351, Universitário. 58429-500 Campina Grande PB Brasil. alinea.fje@gmail.com

\begin{abstract}
The aim of this integrative review was to compare Latin American literature about risk and knowledge on breast cancer. Of 47 studies selected, 20 were about knowledge or awareness and 27 about risk of breast cancer. English was the dominant language in studies about risk, whereas studies about knowledge were mainly written in Spanish or Portuguese. Studies about knowledge were all cross- sectional, whereas case- control studies dominated authors' interest about risk of breast cancer. Studies about knowledge were mainly focused on early detection of the disease and the most common study objective was breast self- examination $(N=14)$. In contrast, few studies about risk of breast cancer focused on early detection $(N=5)$. Obesity and overweight $(N=$ $14)$, family history $(N=13)$, decreased parity ( $N$ $=12)$, and short breastfeeding duration $(N=10)$ were among the most frequent identified risk factors. Socio-economic factors such as income and educational level had variable effects on breast cancer risk and affected also knowledge of women about risk factors and early detection. Present results indicated that studies about risk of breast cancer were more often based on a better sound analytical background, compared to studies about knowledge, which were mostly descriptive.
\end{abstract}

Key words Breast cancer, Early detection of cancer, Risk factors, Knowledge
Resumo Esta revisão teve por objetivo comparar a literatura Latino-Americana sobre o conhecimento da neoplasia mamária e seus fatores de risco. Foram selecionados 47 estudos, dos quais 27 eram sobre o risco de desenvolver câncer de mama e 20 sobre o conhecimento ou a consciência sobre a doença. Os estudos sobre fatores de risco eram principalmente do tipo caso-controle e sua maioria estava no idioma Inglês. Já as pesquisas sobre conhecimento eram, sobretudo, do tipo transversal e foram publicadas nos idiomas Português e Espanhol. As pesquisas sobre conhecimento destacaram o diagnóstico precoce da neoplasia mamária, e o autoexame da mama foi o método de detecção mais abordado $(N=14)$. Por outro lado, os estudos sobre fatores de risco avaliaram, principalmente, sobrepeso $(N=14)$, historia familiar $(N=$ 13), baixa paridade $(N=12)$ e curto período de amamentação $(N=10)$. Fatores socioeconômicos, como a renda e o nivel educacional tiveram efeitos variáveis e afetaram também o conhecimento das mulheres sobre fatores de risco e detecção precoce. Os resultados da pesquisa indicaram que os estudos sobre fatores de risco do câncer de mama apresentaram melhor delineamento metodológico e fundamentação teórica, comparado com os estudos sobre conhecimento que foram na maioria dos casos descritivos.

Palavras-chave Câncer de mama, Diagnóstico precoce, Fatores de risco, Conscientização 


\section{Introduction}

The global burden of breast cancer (BC) is progressively shifting from developed to developing countries ${ }^{1,2}$. According to the Pan American Health Organization (PAHO), BC is the most common and also leading cause of death by cancer among women in Latin America and the Caribbean region, where each year 114.000 women are diagnosed and an estimated 37.000 patients die from this disease ${ }^{3}$. With exception of Guatemala, Honduras and El Salvador, BC ranks in all Latin American countries as one of the three most leading causes of death by cancer among women ${ }^{4}$. Aging combined with decreased fertility rates has caused a demographic shift of societies in these countries ${ }^{3}$. As aging is the most important risk factor of $\mathrm{BC}$, the number of deaths is expected to double by 2013 each year to 74.000 if current trends are confirmed ${ }^{3}$.

Changing lifestyle and reproductive patterns in Latin American countries may additionally increase the risk of $\mathrm{BC}^{5,6}$. In literature, delayed childbearing, low parity and short breastfeeding periods represent well-established reproductive risk factors for $\mathrm{BC}^{7-9}$. Additionally, early age at menarche and late age at menopause are reproductive factors that increase the risk of the disease ${ }^{7}$. Obesity and overweight are also risk factors for $\mathrm{BC}^{6,10}$. Other well-established lifestyle-related risk factors are physical inactivity and sedentarism, alcohol consumption, smoking and intake of several hormones like estrogens ${ }^{11}$. High intake of red meat was identified as a risk factor, whereas high intake of fruits and some dietary patterns such as the Mediterranean diet provided a protective effect ${ }^{11,12}$.

If on the one hand, risk factors such as age or family history are not modifiable, on the other hand, lifestyle-related risk factors like smoking, alcohol consumption or overweight and also reproductive risk factors like breastfeeding are rather modifiable. Avoidance behaviour of modifiable risk factors depends on lifestyle and socioeconomic background and has been associated with the knowledge of women about $\mathrm{BC}^{13,14}$.

Early detection (ED) of BC comprises mammography, clinical breast examination and breast self-examination $(B S E)^{1,14,15}$. Similarly to the women's avoidance behaviour of risk factors, ED through participation on screening programs and BSE depends on knowledge about BC, awareness of its risk, which can be associated to the socio-economic status of women ${ }^{1,15,16}$.

According to most recent data published by PAHO in all Latin American countries, with the exception of Peru, clinical breast examination is available for women by the private and public health sector ${ }^{4}$. Mammography in contrast, is not available by the public but only by the private sector in Bolivia, the Dominican Republic, Ecuador, El Salvador, Guatemala, Honduras, Panama and Paraguay, whereas in Peru, it is not available at all ${ }^{4}$. Information about prevailing risk factors, ED behaviour and women's knowledge about the disease may be important to improve public health politics. In Brazil for example, the Latin American country with the largest population, prevention strategy of $\mathrm{BC}$ are mainly focused on $\mathrm{ED}$ and so far, there is no public information campaign about risk factors ${ }^{17}$. A recent study identified breastfeeding as a protective factor in a population of North-eastern Brazil ${ }^{18}$. In this region, $\mathrm{BC}$ mortality rate increased $5.3 \%$ annually during the last decade ${ }^{19}$.

To the best of our knowledge, there is no comparison of Latin American literature about knowledge and risk of BC. We hypothesized that literature about knowledge of risk and ED would be scarce compared to studies about prevailing risk factors and women's screening behaviour. Furthermore, we asked if Latin American studies about BC are more frequently focused on ED or identification of prevailing risk factors. In relation to Latin American studies on BC prevention, the present review addressed on following four basic questions: 1 . Which Latin American studies on the risks of $\mathrm{BC}$ were performed in the last five years and which risk factors were identified in these studies? 2. How many studies on ED were performed focusing on women's screening behaviour and which forms of ED were analysed? 3. Studies about knowledge and awareness of BC aimed at which are the risk factors and forms of ED? 4. What have been the methods applied by the authors of these Latin American studies?

\section{Method}

An integrative review of the risk factors for $\mathrm{BC}$ and knowledge about them was conducted as previously described ${ }^{20}$. According to established criteria, the operational steps were conducted as followed: Definition of exclusion and inclusion criteria and database; selection of studies; extraction of information and categorization; Analysis and interpretation of data; Interpretation of results; Synthesis and resume of results. The search was conducted in the following databases: $\mathrm{Na}$ tional Library of Medicine (MEDLINE), PubMed; 
Scientific Electronic Library Online (SciELO) and in Literatura Latino-Americana e do Caribe em Ciências da Saúde (Lilacs).

Terms such as "breast cancer", "risk factor", "risk", "knowledge" and "awareness" were identified in Medical Subject Headings (MeSH; http:// www.nlm.nih.gov/mesh/MBrowser.html), of the U. S. National Library of Medicine. To identify a broader range of publications from Latin American countries, the term "risk" was applied instead of "risk factors". The term "breast cancer" was used in combination with "risk", "knowledge" or in combination with "awareness". All three combinations were used in English, Spanish ("Cáncer de mama" and "factor de riesgo", or "conocimiento" or "conciencia") and Portuguese ("Câncer de mama" and "fator de risco", or "conhecimento", or "consciência").

The search was conducted from 2 to 5 of March 2015. To establish an internal quality control, the literature selection procedure was performed twice independently by two of the authors. In the study, articles published during the last five years were included. By applying three combinations of search terms in Medline, 66.782 articles were identified. The application of filters "five years" and "free full text" led to the iden- tification of 9.561studies in Medline (Figure 1). Combinations of search terms in all three languages led to the identification of 592 articles in the SciELO database that have been published within the last five years (Figure 1). Finally, in the Lilacs database, no article that met the criteria of search terms in any of the three languages was identified.

All together, 10.153 articles were used for further analysis (Figure 1). To select articles, title, abstract, authors' information and if necessary results were analysed. The following inclusion criteria were adopted: original research article or research communication, available for free and published over the last five years, in English, Spanish or Portuguese. Articles on BC that did not deal with risk factors or knowledge about them and review articles were excluded from the study. Articles on heritable genetic factors or viral infections that increase the risk of $\mathrm{BC}$ were also excluded from the study. Finally, 27 and 34 articles were selected from Medline and SciELO database, respectively (Figure 1). Articles repeated in different databases or with distinct selection terms, were also excluded (Figure 1). For further categorization, result, method and discussion sections were read and analysed. According to

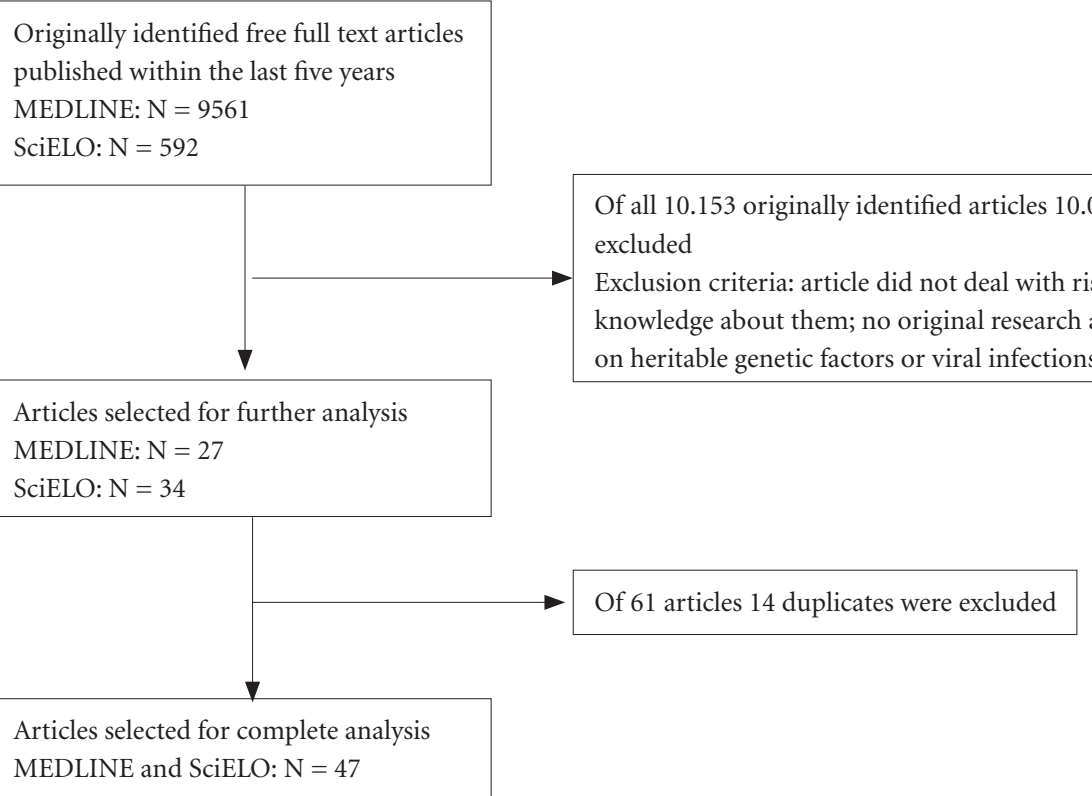

Figure 1. Flowchart of selection of articles. 
previous studies, ED comprised mammography screening, breast examination and $\mathrm{BSE}^{21}$.

All statistical analyses were performed on Prism $^{\mathrm{TM}}$ software vers.6 (GraphPad, La Jolla, California, USA). The t-Test and Mann-Whitney $(\mathrm{U})$ Test were applied to analyse continuous variables. The $\chi^{2-}$ Test was performed to analyse categorical variables.

\section{Results and discussion}

Language variations among studies on risk factors and knowledge about $\mathrm{BC}$

Combination of search terms "breast cancer" and "risk" led to the identification of 27 different articles that met the selection criteria (Table 1). Of these, 17 articles were written in English, eight in Spanish and two in Portuguese (Table 1). The search terms "breast cancer" and "knowledge" or "awareness" led to the identification of 20 different articles that met the selection criteria (Table 1). Of these, four were written in English, nine in Spanish and seven in Portuguese (Table 1).

Results indicated that the authors of studies on knowledge and awareness about BC preferentially published in Spanish or Portuguese, whereas studies on the risk of $\mathrm{BC}$ were mainly written in English ( $p=0.0094$; Chart 1). The authors of studies on knowledge and awareness about BC may have dedicated their work more often to a national or even local population and therefore preferred to publish in their native language. The authors of studies on the risk of BC in contrast, compared their results mainly with those obtained from other populations of different countries. In this case, it may have been more interesting to reach a broader population with studies written in English. This interpretation was supported by the fact that Latin American authors of 25 studies on the risk of BC mainly cited international literature published in English. There were only two exceptions of studies whose authors cited mainly previous publications of their own country written in Spanish and Portuguese ${ }^{22,23}$. In contrast, 16 studies on the knowledge and awareness about BC cited mainly previous publications of their own country written in Spanish or Portuguese $(\mathrm{p}<0.0001)$. There were only four studies on the knowledge and awareness that mainly cited literature published in English ${ }^{24-27}$.

\section{The meaning of the term risk varied among studies}

Articles on the risk of $\mathrm{BC}$ were from Cuba $(\mathrm{N}$ $=1)$, Colombia $(\mathrm{N}=2)$, Venezuela $(\mathrm{N}=2)$, Chile $(\mathrm{N}=3)$, Uruguay $(\mathrm{N}=5)$, Brazil $(\mathrm{N}=6)$ and Mexico $(\mathrm{N}=8$; Chart 1). Of the 27 studies identified by terms "Risk" and "Breast cancer", 22 were exclusively focused on risk factors, whereas five studies focused on ED (Chart 1). The authors of two out of these five studies defined non-participation on ED and BSE as risk (Chart 1$)^{28,29}$. Their

Table 1. Articles identified using all three search-term combinations from 9 of March 2015, found in PubMed and SciELO databases.

\begin{tabular}{|c|c|c|c|c|}
\hline & PubMed & SciELO & Duplicates $^{* *}$ & All selected \\
\hline \multicolumn{5}{|c|}{ Search terms: "Breast cancer" and "risk" } \\
\hline Without filter & 55401 & 417 & - & \\
\hline With filter ${ }^{*}$ & 7596 & - & - & \\
\hline Selected & 19 & 14 & 6 & 27 \\
\hline \multicolumn{5}{|c|}{ Search terms: "Breast cancer" and "knowledge" } \\
\hline Without filter & 9317 & 137 & - & \\
\hline With filter ${ }^{*}$ & 1566 & - & - & \\
\hline Selected & 6 & 17 & 6 & 17 \\
\hline \multicolumn{5}{|c|}{ Search terms: "Breast cancer" and "awareness" } \\
\hline Without filter & 2064 & 38 & & \\
\hline With filter ${ }^{*}$ & 399 & - & & \\
\hline Selected & 2 & 3 & 2 & 3 \\
\hline Total number of articles selected & & & & 47 \\
\hline
\end{tabular}

* Full text articles published within the last five years. ${ }^{* *}$ Found in more than one database or found two times by different search terms. 
Chart 1. Studies identified by the combination of search terms "risk" and "breast cancer".

\begin{tabular}{|c|c|c|c|c|c|}
\hline \multirow{2}{*}{ Reference } & \multirow{2}{*}{$\begin{array}{c}\text { Country and } \\
\text { Language }^{*}\end{array}$} & \multirow{2}{*}{$\begin{array}{c}\text { Sample Size }^{* *} \text { and } \\
\text { Type }\end{array}$} & \multicolumn{2}{|c|}{ Methodological approach } & \multirow{2}{*}{$\begin{array}{c}\text { Objective } \\
\text { (RF/ED) }\end{array}$} \\
\hline & & & Type of Study & Analysis & \\
\hline Amadou et al., $2013^{21}$ & $\begin{array}{l}\text { Mexico } \\
\text { English }\end{array}$ & $\begin{array}{l}1000 \text { BC cases } \\
1074 \text { controls }\end{array}$ & Case-control & Multivariate & $\mathrm{RF}$ \\
\hline Amadou et al., 2014 & $\begin{array}{l}\text { Mexico } \\
\text { English }\end{array}$ & $\begin{array}{l}1000 \text { BC cases } \\
1074 \text { controls }\end{array}$ & Case-control & Multivariate & $\mathrm{RF}$ \\
\hline Balderas-Peña et al., $2013^{31}$ & $\begin{array}{l}\text { Mexico } \\
\text { Spanish }\end{array}$ & 43 healthy women & Cross-sectional & Univariate & $\mathrm{RF}$ \\
\hline Bering et al., $2015^{32}$ & $\begin{array}{l}\text { Brazil } \\
\text { English }\end{array}$ & $78 \mathrm{BC}$ cases & Cross-sectional & Univariate & $\mathrm{RF}$ \\
\hline Matos et al., $2010^{22}$ & $\begin{array}{l}\text { Brazil } \\
\text { Portuguese }\end{array}$ & 439 healthy women & Cross sectional & Multivariate & $\mathrm{RF}$ \\
\hline Matos et al., $2011^{33}$ & $\begin{array}{l}\text { Brazil } \\
\text { Portuguese }\end{array}$ & 439 healthy women & Cross-sectional & Multivariate & ED \\
\hline Fejerman et al., $2010^{34}$ & $\begin{array}{l}\text { Mexico } \\
\text { English }\end{array}$ & $\begin{array}{l}846 \mathrm{BC} \text { cases } 1035 \\
\text { controls }\end{array}$ & Case- control & Multivariate & $\mathrm{RF}$ \\
\hline $\begin{array}{l}\text { Garmendia et al., } \\
2013^{35}\end{array}$ & $\begin{array}{l}\text { Chile } \\
\text { Spanish }\end{array}$ & Database & Ecological & Univariate & $\mathrm{RF}$ \\
\hline Girianelli et al., 2014 & \begin{tabular}{|l} 
Brazil \\
English
\end{tabular} & Database & Ecological & Univariate & $\mathrm{RF}$ \\
\hline Inumaru et al., $2012^{37}$ & \begin{tabular}{|l} 
Brazil \\
English \\
\end{tabular} & $\begin{array}{l}93 \mathrm{BC} \text { cases } \\
186 \text { controls } \\
\end{array}$ & Case-control & Multivariate & $\mathrm{RF}$ \\
\hline Iwasaki et al., $2011^{38}$ & \begin{tabular}{|l|} 
Brazil-Japan \\
English
\end{tabular} & 363 healthy women & Cross-sectional & Multivariate & $\mathrm{RF}$ \\
\hline López-Carrillo et al., $2010^{39}$ & $\begin{array}{l}\text { Mexico } \\
\text { English }\end{array}$ & $\begin{array}{l}233 \text { BC cases } \\
221 \text { controls }\end{array}$ & Case-control & Multivariate & $\mathrm{RF}$ \\
\hline López-Carrillo et al., $2014^{28}$ & $\begin{array}{l}\text { Mexico } \\
\text { Spanish }\end{array}$ & 1030 healthy women & Cross-Sectional & Multivariate & ED \\
\hline Pereira et al., $2012^{40}$ & $\begin{array}{l}\text { Chile } \\
\text { English } \\
\end{array}$ & $\begin{array}{l}170 \text { BC cases } \\
170 \text { controls } \\
\end{array}$ & Case-control & Multivariate. & $\mathrm{RF}$ \\
\hline Ronco et al., 2011 & $\begin{array}{l}\text { Uruguay } \\
\text { English }\end{array}$ & $\begin{array}{l}460 \text { BC cases } \\
638 \text { controls } \\
\end{array}$ & Case-control & Multivariate & $\mathrm{RF}$ \\
\hline Ronco et al., $2012^{42}$ & $\begin{array}{l}\text { Uruguay } \\
\text { English }\end{array}$ & $\begin{array}{l}367 \mathrm{BC} \text { cases } \\
545 \text { controls }\end{array}$ & Case-control & Multivariate & $\mathrm{RF}$ \\
\hline Ronco et al., $2012^{43}$ & $\begin{array}{l}\text { Uruguay } \\
\text { English }\end{array}$ & $\begin{array}{l}253 \text { BC cases } \\
497 \text { controls }\end{array}$ & Case-control & Multivariate & $\mathrm{RF}$ \\
\hline De Stefani et al., $2011^{44}$ & $\begin{array}{l}\text { Uruguay } \\
\text { English }\end{array}$ & $\begin{array}{l}8875 \text { BC cases } \\
4326 \text { controls }\end{array}$ & Case- Control & Multivariate & $\mathrm{RF}$ \\
\hline De Stefani et al., $2012^{45}$ & $\begin{array}{l}\text { Uruguay } \\
\text { English }\end{array}$ & \begin{tabular}{|l}
3528 cases of \\
different cancers \\
2532 controls \\
\end{tabular} & Case-control & Multivariate & $\mathrm{RF}$ \\
\hline Cordero et al., $2012^{46}$ & $\begin{array}{l}\text { Mexico } \\
\text { Spanish }\end{array}$ & $\begin{array}{l}115 \text { BC cases } \\
115 \text { controls }\end{array}$ & Case-control & Multivariate & $\mathrm{RF}$ \\
\hline Cabello et al., $2013^{47}$ & $\begin{array}{l}\text { Chile } \\
\text { English }\end{array}$ & $158 \mathrm{BC}$ cases & Cross-sectional & Univariate & $\mathrm{RF}$ \\
\hline
\end{tabular}


Chart 1. continuation

\begin{tabular}{|c|c|c|c|c|c|}
\hline \multirow{2}{*}{ Reference } & \multirow{2}{*}{$\begin{array}{c}\text { Country and } \\
\text { Language }^{*}\end{array}$} & \multirow{2}{*}{$\begin{array}{c}\text { Sample Size }{ }^{* *} \text { and } \\
\text { Type }\end{array}$} & \multicolumn{2}{|c|}{ Methodological approach } & \multirow{2}{*}{$\begin{array}{l}\text { Objective } \\
\text { (RF/ED) }\end{array}$} \\
\hline & & & Type of Study & Analysis & \\
\hline $\begin{array}{l}\text { Calderón- Garcidueñas et } \\
\text { al., } 2012^{48}\end{array}$ & $\begin{array}{l}\text { Mexico } \\
\text { English }\end{array}$ & 300 healthy women & Cross-sectional & Multivariate & ED \\
\hline Rodríguez et al., $2013^{23}$ & $\begin{array}{l}\text { Cuba } \\
\text { Spanish }\end{array}$ & 70 BC cases & Cross sectional & Descriptive & RF \\
\hline Ferri et al., $2010^{49}$ & $\begin{array}{l}\text { Venezuela } \\
\text { Spanish }\end{array}$ & $\begin{array}{l}100 \text { BC cases } \\
103 \text { controls }\end{array}$ & Case-control & Univariate & RF \\
\hline Font-Gonzalez et al., $2013^{50}$ & $\begin{array}{l}\text { Colombia } \\
\text { English }\end{array}$ & $\begin{array}{l}\text { Database } \\
27.116 \text { healthy } \\
\text { women }\end{array}$ & Cross-sectional & Multivariate & ED \\
\hline Hernández et al., $2010^{51}$ & $\begin{array}{l}\text { Venezuela } \\
\text { Spanish }\end{array}$ & $\begin{array}{l}507 \text { BC cases } \\
505 \text { controls }\end{array}$ & Case-control & Multivariate & RF \\
\hline Ospina-Díaz et al., $2011^{29}$ & $\begin{array}{l}\text { Colombia } \\
\text { Spanish }\end{array}$ & $\begin{array}{l}218 \text { BC cases } \\
225 \text { controls }\end{array}$ & Case-control & Univariate. & ED \\
\hline
\end{tabular}

Abbreviations: $\mathrm{BC}=$ breast cancer; $\mathrm{ED}=$ Early detection; $\mathrm{RF}=$ Risk factors. Sampling numbers were not informed. *Studies were mainly written in English $\left(\chi^{2-}\right.$ Test; $\left.p=0.0094\right){ }^{* *}$ The average sample number was 363.0 cases ( $\left.\mathrm{t}-\mathrm{Test} ; \mathrm{p}=0.0552\right)$.

studies focused on determinants of women's behaviour regarding ED and the correct application of BSE: In a Colombian case- control study, Ospina-Díaz et al. analysed women's behaviour of BSE, and defined behavioural risk factors that were susceptible to educative intervention (Chart $2)^{29}$. Similarly, one Mexican study focused on socio-economic background of women and risk factors that affect ED (Chart 2) 28 . The authors of this study also analysed the correct application of BSE.

Alternatively, in the context of ED, authors determined different risk groups that were agedependent (Chart 1) ${ }^{33,50}$ : Carvalho de Matos et al. ${ }^{33}$ interviewed 439 healthy women about ED behaviour (Chart 2). In a Colombian study that included data from 27.116 healthy women, ED behaviour was analysed and different risk groups were defined $(\text { Chart } 2)^{50}$.

\section{Identified risk factors of $\mathrm{BC}$}

In studies on the risk of BC, obesity and overweight $(\mathrm{N}=14)$, positive menopause status $(\mathrm{N}$ = 13), family history of $\mathrm{BC}(\mathrm{N}=13)$, early age at menarche $(\mathrm{N}=12)$, nulliparity or decreased parity $(\mathrm{N}=12)$, older age $(\mathrm{N}=12)$ and short breastfeeding duration $(\mathrm{N}=10)$ were the most often identified risk factors (Chart 2). Risk factors were subdivided into four main categories: Lifestyle-related, reproductive, socio economic and environmental risk factors, respectively, a category of history of BC (Chart 2). Several authors have analysed risk factors of all four categories $^{30,34,37,38,40-42}$. Two studies performed in Uruguay for example, included a broad range of different risk factors ${ }^{41,42}$. The author's decision to analyse several distinct and unrelated risk factors may have been influenced by the high incidence of BC in Uruguay.

Most studies focused on a specific topic or a complex of thematically related risk factors: Amadou et al. for example, analysed in their study the effect of hormone replacement therapy and contraceptive use on the risk of BC (Chart 2) ${ }^{21}$. Iwasaki et al. compared blood concentrations of several sex hormones among Japanese and Brazilian women of Japanese ancestry ${ }^{38}$. This exceptional comparative study revealed that Brazilian women of Japanese ancestry had increased blood concentrations of several sex hormones like estradiol and testosterone ${ }^{38}$. Populations differed regarding several risk factors and increased hormone concentrations were positively associated with body mass index (BMI; Chart 2$)^{38}$. The study of Ronco et al. was the only one that identified diabetes as a risk factor for BC (Chart 2) ${ }^{42}$. The authors determined the risk of diabetes in combination with overweight, high fat-to-muscle ratio and hypertension (Chart 2$)^{42}$. In a similar study, Bering et al. described a high prevalence of increased body mass index (BMI), high levels 
Chart 2. Summary of risk factors identified by 27 studies on the risk of BC.

\begin{tabular}{|c|c|}
\hline Risk Factor & Reference \\
\hline \multicolumn{2}{|l|}{ Early detection } \\
\hline No mammography & $22,28,33,50$ \\
\hline No clinical breast examination & $22,28,33,50$ \\
\hline No BSE & $22,28,29,33,50$ \\
\hline \multicolumn{2}{|l|}{ Reproductive } \\
\hline Early age at menarche & $21,22,23,32,34,38,39,41,42,43,46,48$ \\
\hline Positive status of menopause & $22,23,31,32,34,38,40,41,42,43,46,48,51$ \\
\hline Nulliparity or decreased parity & $21,22,30,34,38,39,40,41,42,43,46,51$ \\
\hline Short total breastfeeding time & $21,22,23,30,34,39,42,43,46,51$ \\
\hline Old age at first gestation & $21,30,38,39,42,46$ \\
\hline \multicolumn{2}{|l|}{ Lifestyle- related } \\
\hline Smoking & $22,23,38,40,46,48$ \\
\hline High alcohol consumption & $21,22,30,34,38,40,41,42,46,48$ \\
\hline No physical exercise and sedentarism & $21,23,29,30,37,38,40,42,43,46$ \\
\hline Overweight and obesity & $21,22,23,31,32,34,35,38,40,42,43,46,48,49$ \\
\hline Diet rich in fried foods and/or meat & $21,40,41,42,43,44,45,50$ \\
\hline Diet poor in vegetables and fruits & 43 \\
\hline Increased caloric intake & 30,34 \\
\hline Decreased BMI & 30,34 \\
\hline Increased BMI & $32,38,46$ \\
\hline Round body shape (Endomorphy) & $30,32,41$ \\
\hline Diabetes & 42 \\
\hline Hypertension & $31,40,42,43$ \\
\hline Hormone replacement therapy & $21,22,30,32,34,40,48$ \\
\hline Use of contraceptives & $21,30,40,42,43$ \\
\hline Harmful hormone concentrations & 32,38 \\
\hline \multicolumn{2}{|c|}{ Ethical, socioeconomic and environment factors } \\
\hline Increased educational level & $34,36,40$ \\
\hline Decreased educational level & $22,29,37,50$ \\
\hline Increased HDI & 36 \\
\hline Lower income & $22,29,37,50$ \\
\hline Higher income & $22,30,34$ \\
\hline No Caucasian or Caucasian ancestry & 34,50 \\
\hline Rural living place & $37,41,50$ \\
\hline Chemical contaminants & 39,47 \\
\hline \multicolumn{2}{|l|}{ Age and history of breast cancer } \\
\hline Family history of breast cancer & $21,22,23,30,34,37,40,41,42,43,47,48,51$ \\
\hline Personal history of breast cancer & $22,34,51$ \\
\hline Older age & $28,30,32,33,34,37,39,40,41,42,47,50$ \\
\hline
\end{tabular}

Abbreviations: $\mathrm{BMI}=$ Body mass index; HDI = Human development index.

of cholesterol, round body shape, overweight and obesity among $78 \mathrm{BC}$ patients in Brazil (Chart $2)^{32}$. In this study, a set of body shape associated nutritional status parameters were analysed. Association between body shape and risk of BC was also the objective of a Mexican study performed 
by Amadou et al. ${ }^{30}$. High prevalence of overweight and obesity in Latin American countries may explain the author's interest in these risk factors, body shape and BMI.

Two studies identified increased BMI as risk factor (Chart 2) $)^{32,46}$. In contrast, two other studies identified decreased BMI as risk factor, in pre and post- menopause women, respectively (Chart $2)^{30,34}$. As all these three studies were from Mexico, it was difficult to attribute population-based biological differences. Furthermore, logistic regression modelling showed in each study that BMI represented an independent variable. It was also pointed out that findings about BMI as risk factor are contradictory ${ }^{32}$. Therefore, the context in which BMI acts as a risk factor remained unresolved.

\section{Education and income} were context-dependent risk factors of BC [

In studies on the risk of $\mathrm{BC}$, four authors identified decreased educational level as risk factor (Chart 2) ${ }^{22,29,37,50}$. In contrast, three authors identified increased educational level as risk factor (Chart 2) ) $34,36,40$. Decreased educational level may explain increased risk of non-participation on screening programs and BSE in three out of four studies (Chart 2) 22,29,50. This argument cannot explain the results of Inamuru et al., who compared in a case- control study several reproductive risk factors among women from rural regions and urbanized centres of Mid-western Brazil (Chart 2) ${ }^{37}$ : Additionally, the authors of this study also identified lower income and decreased educational level as risk factors for women living in rural areas (Chart 2) ${ }^{37}$. In contrast, two studies from Mexico and Chile that identified higher educational level as risk factor were based on data obtained from hospitals of urban centres (Chart $2)^{34,40}$. The third study that identified higher educational level as risk factor was based on a large data set of $\mathrm{BC}$ mortality rates and selected socioeconomic and health care indicators in Brazil ${ }^{36}$. The latter study included data from urbanized centres and rural regions.

Results indicated that the effect of education on the risk of $\mathrm{BC}$ was different in urbanized centres compared to rural regions. Education can have a direct effect on ED behaviour, but it is not a direct risk factor of BC. Therefore, increased and decreased educational level may be associated in distinct ways with reproductive and lifestyle-related risk factors in rural regions and urbanized centres. This argument was supported by the fact that regression modelling revealed several independent reproductive and lifestyle-related risk factors, whereas increased educational level was not identified as an independent variable ${ }^{34,40}$.

Similarly, two Mexican studies based on data obtained from hospitals of urban centres identified high income as risk factor, in contrast to a Brazilian study, which identified low income and living in rural areas as risk factors (Chart $2)^{30,34,37}$. Low income was also identified as a risk factor for ED behaviour in studies from Brazil and Colombia (Chart 2) 29,37,50. Carvalho de Matos et al. showed that mammography screening behaviour was positively associated with high income, whereas clinical breast examination was less common among women with high socioeconomic status (Chart 2) ${ }^{22}$.

\section{Methodological approaches differed considerably among studies on the risk and knowledge about BC}

Of the 27 studies on the risk of BC, 24 were based on interviews. In a Chilean study on the relationship between $\mathrm{BC}$ and malathion aerial spraying, Cabello et al. extracted additional data on $\mathrm{BC}$ patients from medical records ${ }^{47}$. Three studies used databases instead of interviews (Chart 1) $)^{35,36,50}$. Most studies were case-control $(\mathrm{N}=15)$ or cross- sectional $(\mathrm{N}=10)($ Chart 1$)$. Sampling numbers varied from 93 to 8.875 cases for case-control studies and from 43 to 27.116 cases or healthy women for cross-sectional studies (Chart 1).

Several studies on the risk of $\mathrm{BC}(\mathrm{N}=7)$ exclusively applied univariate methods to analyse data (Chart 1). In this case, methods included descriptive statistics like t-Test, $\chi^{2-}$ Test, correlation analysis and also univariate logistic regression. Balderas-Peña et al., for example, analysed correlations between expression of hormone receptors, obesity and hypertension, respective$1 y^{31}$. To express odds ratios, the authors applied univariate logistic regression. Most studies on the risk of $\mathrm{BC}$ applied multivariate logistic regression to analyse data $(\mathrm{N}=19$; Chart 1$)$. These studies were typically composed of two analytical steps: Hernández et al. for example, compared different risk factors between patients with benign and invasive BC and healthy women ${ }^{46}$. Firstly, the authors applied univariate statistical analysis to detect significant differences among the three groups. To reveal which of these variables, increase risk of BC independently, multivariate logistic regression was applied. In this study, fam- 
ily history was the unique independent variable.

In contrast to most studies on the risk of $\mathrm{BC}$, the authors of studies on the knowledge and awareness about $\mathrm{BC}$ did not perform case- control studies ( $p<0.0001$; Chart 3). All 20 studies on the knowledge and awareness about BC were cross- sectional and data sampling was based on interviews. Sample numbers varied from 18 to 1899 cases of BC or healthy women (Chart 3). The average sample number of studies on the knowledge and awareness about BC was 117.5, compared to 363.0 studies on the risk of BC (p $=0.0552$; Chart 1). Furthermore, in contrast to studies on the risk of $\mathrm{BC}$, most studies on the knowledge and awareness about BC $(\mathrm{N}=16)$ did not use any statistical method to analyze data, but were purely descriptive $(\mathrm{p}<0.0001$; Chart 3$)$. Six studies on the knowledge and awareness about $\mathrm{BC}$ were intervention studies performed in Cuba and Brazil ${ }^{52-57}$. Grego et al. for example, applied a questionnaire before and after a workshop and did not perform any statistical analysis ${ }^{52}$. Hechvarría et al. in contrast, analyzed concordance between data obtained before and after a workshop $^{54}$. Only two out of 20 studies on the knowledge and awareness about BC performed multivariate regression analysis: Banegas et al., and Oliveira-Brito et al. applied multivariate logistic regression to analyze factors that affect women's perceived risk of $\mathrm{BC}$ and socio-economic factors associated with BSE, respectively ${ }^{24,58}$.

Present results indicated that Latin American studies on the knowledge and awareness about BC used more often, descriptive methodological approach and smaller sample size. Interestingly, no case- control study on the knowledge and awareness about BC was identified. The lack of case-control approach may be due to the idea that women's knowledge about risk factors of BC and ED might improve during the course of the disease, leading to a bias of sampled data. Furthermore, knowledge about modifiable risk factors does not necessarily affect women's prevention behavior.

\section{Studies on the knowledge and awareness about the risk of $\mathrm{BC}$ were mainly focused on ED}

Articles on the knowledge or awareness about BC were from Chile $(\mathrm{N}=1)$, Venezuela $(\mathrm{N}=1)$, Mexico $(\mathrm{N}=2)$, Cuba $(\mathrm{N}=5)$ and Brazil $(\mathrm{N}=$ 11; Chart 3). Few studies on the risk factors were focused on ED (Chart 1). In contrast, 12 out of 20 studies on knowledge and awareness were exclu- sively focused on ED, two on risk factors and six on both, ED and risk factors ( $\mathrm{p}<0.0001$; Chart 3 ). This result indicated that authors interested in women's knowledge on BC prevention were mainly focused on ED. There might be different reasons for this preference: Curiel et al. argued in their Mexican study that many women in Latin American countries, mainly from rural areas, have no knowledge about ED at all ${ }^{59}$. The authors pointed to socio economic and geographic barriers, limiting possibilities of ED. Similarly, the authors of studies carried out in Brazil exclusively focused on women's knowledge about ED emphasized the existence of social and geographical barriers that limit possibilities of mammography and clinical breast examination ${ }^{26,60}$. Silva et al., pointed out in their study that ED techniques have been largely studied in developed countries and little is known about their efficiency in developing countries ${ }^{25}$. In one case, the authors also argued that possibilities to avoid risk of BC are limited, as causal relationships between these risk factors and disease have not been well established ${ }^{60}$.

Interestingly, none of the 16 studies on ED included questions about knowledge regarding possible disadvantages of clinical BC screening, like false- positive diagnosis, or unnecessary operative and chemotherapeutic interventions. Both represent well-known harms of mammography and clinical breast examination ${ }^{61,62}$. Furthermore, in their interviews, the authors of these 16 studies did not ask women if screening techniques may serve to prevent or alternatively to early detect the breast tumour.

\section{Most studies on the knowledge of ED were based on BSE}

The most often cited objectives of BC studies on the knowledge and awareness were BSE $(\mathrm{N}=$ $14)$, mammography $(\mathrm{N}=7)$ clinical breast examination $(\mathrm{N}=6)$, followed by short total breastfeeding time, smoking and family history of BC $(\mathrm{N}=4$; Chart 4). The fact that BSE dominated literature of knowledge about ED was surprising because, as pointed out by Oliveira- Brito et al., there is no direct evidence of reduction of mortality by BSE ${ }^{58}$. The authors of this Brazilian study emphasized that, especially for women from developing countries, easy performance and low costs of BSE may be helpful to detect early breast alterations ${ }^{58}$. Less than half of women performed $\mathrm{BSE}^{58}$. The authors of other studies argued that despite the ongoing debate, BSE may significantly contribute to the ED of breast tumours ${ }^{60,63}$. 
Chart 3. Studies identified by the search term combinations "breast cancer" and "knowledge" or "awareness".

\begin{tabular}{|c|c|c|c|c|}
\hline Reference & $\begin{array}{l}\text { Country and } \\
\text { Language }\end{array}$ & Sample Size and type & $\begin{array}{c}\text { Methodological } \\
\text { approach }^{*}\end{array}$ & $\begin{array}{l}\text { Objective } \\
(\mathrm{RF} / \mathrm{ED})^{* *}\end{array}$ \\
\hline Banegas et al., $2012^{24}$ & $\begin{array}{l}\text { Chile } \\
\text { English }\end{array}$ & 500 healthy women & Multivariate & RF \\
\hline Silva, Riul, $2011^{64}$ & $\begin{array}{l}\text { Brazil } \\
\text { Portuguese }\end{array}$ & 18 BC cases & Descriptive & ED \\
\hline Silva et al., $2013^{25}$ & $\begin{array}{l}\text { Brazil } \\
\text { English }\end{array}$ & 248 BC cases & Univariate & ED \\
\hline Schneider et al., $2013^{26}$ & $\begin{array}{l}\text { Brazil } \\
\text { English }\end{array}$ & 1899 healthy women & Univariate & ED \\
\hline Grego et al., $2011^{52}$ & $\begin{array}{l}\text { Brazil } \\
\text { English }\end{array}$ & $\begin{array}{l}474 \text { adolescent } \\
\text { women }\end{array}$ & Descriptive & RF and ED \\
\hline Kim et al., $2010^{53}$ & $\begin{array}{l}\text { Brazil } \\
\text { Portuguese }\end{array}$ & 72 healthy women & Descriptive & ED \\
\hline Hechavarría et al., $2011^{54}$ & $\begin{array}{l}\text { Cuba } \\
\text { Spanish }\end{array}$ & 94 healthy women & Univariate & ED \\
\hline Sáez et al., $2011^{55}$ & $\begin{array}{l}\text { Cuba } \\
\text { Spanish }\end{array}$ & 54 BC cases & Descriptive & RF and ED \\
\hline Jacobo-Galindo et al., $2014^{63}$ & $\begin{array}{l}\text { Mexico } \\
\text { Spanish }\end{array}$ & 105 healthy women & Descriptive & ED \\
\hline Muñoz et al., $2012^{65}$ & $\begin{array}{l}\text { Cuba } \\
\text { Spanish }\end{array}$ & 80 healthy women & Descriptive & ED \\
\hline Guerrero et al., $2011^{56}$ & $\begin{array}{l}\text { Cuba } \\
\text { Spanish }\end{array}$ & 119 healthy women & Descriptive & RF and ED \\
\hline Gomes et al., $2012^{66}$ & $\begin{array}{l}\text { Brazil } \\
\text { Portuguese }\end{array}$ & 202 healthy women & Descriptive & ED \\
\hline Brito et al., $2010^{58}$ & $\begin{array}{l}\text { Brazil } \\
\text { Portuguese }\end{array}$ & 552 healthy women & Multivariate & ED \\
\hline Montañez et al., $2011^{57}$ & $\begin{array}{l}\text { Cuba } \\
\text { Spanish }\end{array}$ & 30 healthy women & Univariate & RF and ED \\
\hline Freitas et al., $2011^{67}$ & $\begin{array}{l}\text { Brazil } \\
\text { Portuguese }\end{array}$ & 50 healthy women & Descriptive & $\mathrm{RF}$ \\
\hline Silva et al., $2013^{60}$ & $\begin{array}{l}\text { Brazil } \\
\text { Spanish }\end{array}$ & 116 healthy women & Univariate & ED \\
\hline González et al., $2012^{68}$ & $\begin{array}{l}\text { Venezuela } \\
\text { Spanish }\end{array}$ & 1525 healthy women & Descriptive & RF and ED \\
\hline $\begin{array}{l}\text { Santos, Chubaci, } \\
2011^{69}\end{array}$ & $\begin{array}{l}\text { Brazil } \\
\text { Portuguese }\end{array}$ & 98 healthy women & Univariate & ED \\
\hline Batiston et al., $2011^{27}$ & $\begin{array}{l}\text { Brazil } \\
\text { Portuguese }\end{array}$ & 393 healthy women & Univariate & RF and ED \\
\hline Curiel et al., $2014^{59}$ & $\begin{array}{l}\text { Mexico } \\
\text { Spanish }\end{array}$ & 135 healthy women & Descriptive & ED \\
\hline
\end{tabular}

Abbreviations: $\mathrm{BC}=$ breast cancer; $\mathrm{ED}=$ Early detection; $\mathrm{RF}=$ Risk factors. Authors cited mainly previous publications written in Spanish or Portuguese $\left(\chi^{2-}\right.$ Test; $\left.\mathrm{p}<0.0001\right)$. "Authors did not perform case- control studies $\left(\chi^{2-}\right.$ Test; $\left.\mathrm{p}<0.0001\right)$ and most studies were purely descriptive $\left(\chi^{2-}\right.$ Test; $\left.\mathrm{p}<0.0001\right)$. * Most studies focused exclusively on early detection $\left(\chi^{2-}\right.$ Test; $\left.\mathrm{p}<0.0001\right)$. 
Dongiu Kim et al. argued in their interventional study that ED success could be limited due to insufficient knowledge about it ${ }^{53}$. The author's interest on women's knowledge about mammography screening was mainly encouraged by increased efficiency of this technique compared to BSE in the early detection of breast tumours (Chart 4) ${ }^{25,26,64,69}$. Schneider et al. performed a study about ED that exclusively focused on mammography and pointed out that this screening method reduces mortality by ED of breast tumours of women aged 50-69 years (Chart 4$)^{26}$.

\section{Studies on the knowledge and awareness about BC focused on few modifiable risk factors}

The authors of studies from Cuba emphasized the importance of women's knowledge about BC (Chart 4) $)^{56,68}$. Pires-Batiston et al. analysed the knowledge on several lifestyles related and reproductive risk factors, emphasizing in the introduction of their Brazilian study, that changing lifestyle may contribute to increased risk of BC (Chart 3$)^{27}$. However, in studies on the knowledge and awareness about $\mathrm{BC}$, the number of references per risk factor was low: If ED was excluded in the analysis, the mean number of references in studies on the risk of BC was 5.84 (s $=4.19)$ compared to $2.44(\mathrm{~s}=1.04)$ of studies on the knowledge of $\mathrm{BC}(\mathrm{p}=0.0015)$. On one hand, the decreased number of references of risk factors in studies on the knowledge of BC may be partially explainable by the fact that many of these risk factors are not modifiable and therefore the authors did not focus on women's knowledge about them. On the other hand, many risk factors, especially those related to lifestyle and protective factors like breastfeeding, are modifiable. The knowledge and awareness about these risk factors could change women's behaviour towards avoiding risk of $\mathrm{BC}$.

\section{Socio-economic factors affect women's knowledge}

Studies also aimed at assessing socio- economic factors that influence knowledge about ED. Schneider et al., showed in their study that women with low income, no private health insurance and low educational level participate less frequently in mammography screening programs ${ }^{26}$. Older women had in general better knowledge about ED than younger ones ${ }^{26,58,64,65,66}$. In a study from Venezuela, the authors report-
Chart 4. Summary of knowledge on BC analysed by 20 studies about knowledge and awareness of BC.

\begin{tabular}{|c|c|}
\hline Knowledge & Reference \\
\hline \multicolumn{2}{|l|}{ Early Detection } \\
\hline Mammography & $\begin{array}{l}25,26,27,53,63 \\
64,69\end{array}$ \\
\hline
\end{tabular}

\begin{tabular}{|c|c|}
\hline \multicolumn{2}{|l|}{ Reproductive risk factors } \\
\hline Nulliparity or decreased parity & 55,68 \\
\hline Early age at menarche & 68 \\
\hline Old age at first gestation & 55,68 \\
\hline Positive status of menopause & $55,67,68$ \\
\hline Short total breastfeeding time & $27,55,67,68$ \\
\hline \multicolumn{2}{|l|}{ Lifestyle-related risk factors } \\
\hline Smoking & $27,52,56,68$ \\
\hline Alcohol consumption & $27,52,68$ \\
\hline Use of contraceptives & 56,67 \\
\hline $\begin{array}{l}\text { No physical exercise and } \\
\text { sedentarism }\end{array}$ & 52,67 \\
\hline Diet poor in vegetables and fruits & $27,52,67$ \\
\hline Overweight and obesity & $55,67,68$ \\
\hline Hormone replacement therapy & $27,67,68$ \\
\hline Insufficient auto-care & 27 \\
\hline Stress & 27 \\
\hline Risk perception & 24 \\
\hline \multicolumn{2}{|c|}{ Age and history of breast cancer as risk factors } \\
\hline Family history of breast cancer & $27,55,56,68$ \\
\hline Personal history of breast cancer & $27,55,68$ \\
\hline Older age & 55,68 \\
\hline
\end{tabular}

ed that low income and educational level not only affected knowledge about BSE negatively, but also knowledge about reproductive and life- 
style-related risk factors (Chart 4) ${ }^{68}$. Similarly, a Brazilian study revealed that the knowledge about risk factors was negatively associated with low educational level and family history of $\mathrm{BC}^{27}$.

\section{Final considerations}

Knowledge does not necessarily affect women's behaviour and it is not clear if knowledge about modifiable risk factors alone could lead to a decreased incidence of breast cancer. Case- control studies could help to elucidate the effect of women's knowledge on prevention behaviour of modifiable risk factors. In contrast to modifiable risk factors, knowledge about ED can directly affect women's screening behaviour. On the one hand, this may have led authors to focus their studies on the knowledge mainly on ED and a reduced number of known risk factors for BC. On the other hand, the prevention of identified modifiable risk factors can be easily propagated in media, as it is relatively inexpensive and may be effective in the long-term. Breastfeeding for example, was identified as a protective factor for $\mathrm{BC}$ in a population of North-eastern Brazil and is often propagated as a factor that improves child health, but rarely in the context of $\mathrm{BC}$ prevention ${ }^{17,18}$. Furthermore, knowledge about risk factors that women cannot change in a given phase of their life such as age, age at first gestation or menopause status, could encourage their participation on BC screening programs. Therefore both, identification of prevailing risk factors and women's knowledge about risk of BC and ED are important for public health institutions to develop BC prevention strategies. Information on both types of studies can be used to improve campaigns of $\mathrm{ED}$ and prevention of risk factors. 
All the three authors contributed to acquisition of data. AFA Jerônimo contributed to creation of tables. AFA Jerônimo and AGQ Freitas contributed to manuscript draft and critical review. Study design, manuscript draft and data analysis were mainly performed by $\mathrm{M}$ Weller.

\section{References}

1. Dey S. Preventing breast cancer in LMICs via screening and/or early detection: The real and the surreal. World J Clin Oncol 2014; 5(3):509-519.

2. Ferlay J, Soerjomataram I, Dikshit R, Eser S, Mathers C, Rebelo M, Parkin DM, Forman D, Bray F. Cancer incidence and mortality worldwide: Sources, methods and major patterns in GLOBOCAN 2012. Int J Cancer 2015; 136(5):E359-E386.

3. Pan-American Health Organization (PAHO). A review of breast cancer care and outcomes in Latin America, 2012. [acessado 2015 abr 15]. Disponível em: http:// www.paho.org/Hq/index.php?option=com_content \&view=category\&layout $=$ blog\&id=3400\&Itemid $=$ 3639\&lang=en

4. Pan-American Health Organization (PAHO). Epidemiology of Breast Cancer in the Americas, 2014. [acessado 2015 abr 15]. Disponível em: http://www.paho. org/hq/index.php?option $=$ com_content $\&$ view $=$ category\&layout=blog\&id=1866\&Itemid $=3904$.

5. Amadou A, Torres-Mejía G, Hainaut P, Romieu I Breast cancer in Latin America: global burden, patterns, and risk factors. Salud Publica Mex 2014; 56(5):547-554.

6. Inumaru LE, Quintanilha MIGD, Silveira EA, Naves MMV. Risk and protective factors for breast cancer in Midwest of Brazil. J Environ Public Health 2012; 2012:356851.

7. Anderson KN1, Schwab RB, Martinez ME. Reproductive risk factors and breast cancer subtypes: a review of the literature. Breast Canc Res Treat 2014; 144(1):1-10.

8. França-Botelho AC, Ferreira MC, França JL, França EL, Honório-França AC. Breastfeeding and its Relationship with Reduction of Breast Cancer: A Review. Asian Pac J Cancer Prev 2012; 13(11):5327-5332.

9. Kobayashi S, Sugiura H, Ando Y, Shiraki N, Yanagi T, Yamashita H, Toyama T. Reproductive history and breast cancer risk. Breast Cancer 2012; 19(4):302-308.

10. Kann S, Schmid SM, Eichholzer M, Huang DJ, Amann E, Güth U. The impact of overweight and obesity on breast cancer: data from Switzerland, so far a country little affected by the current global obesity epidemic. Gland Surgery 2014; 3(3):181-197.

11. Kruk J. Lifestyle components and primary breast cancer prevention. Asian Pac J Cancer Prev 2014; 15(24): 10543-10555.

12. Castelló A, Pollán M, Buijsse B, Ruiz A, Casas AM, Baena-Cañada JM, Lope V, Antolín S, Ramos M, Muñoz M, Lluch A, de Juan-Ferré A, Jara C, Jimeno MA, Rosado P, Díaz E, Guillem V, Carrasco E, Pérez-Gómez B, Vioque J, Boeing H, Martín M; GEICAM researchers. GEICAM researchers. Spanish Mediterranean diet and other dietary patterns and breast cancer risk: case-control EpiGEICAM study. Br J Cancer 2014; 111(7):14541462.

13. Liu LY, Wang F, Yu LX, Ma ZB, Zhang Q, Gao DZ, Li YY, Li L, Zhao ZT, Yu ZG. Breast cancer awareness among women in Eastern China: a cross-sectional study. BMC Public Health 2014; 14:1004.

14. Perry Morse E, Maegga B, Joseph G, Miesfeldt S. Breast Cancer Knowledge, Beliefs, and Screening Practices among Women Seeking Care at District Hospitals in Dar es Salaam, Tanzania. Breast Cancer (Auckl) 2014; 8:73-79. 
15. Vithana PC, Ariyaratne M, Jayawardana P. Educational Intervention on Breast Cancer Early Detection: Effectiveness among Target Group Women in the District of Gampaha, Sri Lanka. Asian Pac J Cancer Prev 2015; 16(6):2547-2553.

16. Berens EM, Stahl L, Yilmaz-Aslan Y, Sauzet O, Spallek J, Razum O. Participation in breast cancer screening among women of Turkish origin in Germany- a register-based study. BMC Women's Health 2014; 14:24

17. Instituto Nacional do Câncer (INCA). Tipos de câncer: mama. [acessado 2015 abr 18]. Disponível em: http:// www2.inca.gov.br/wps/wcm/connect/tiposdecancer/ site/home/mama+/prevencao+

18. Almeida GS, Almeida LAL, Araujo GMR, Weller M. Reproductive risk factors differ among breast cancer patients and controls in a public hospital of Paraíba, Northeast Brazil. Asian Pac J Cancer Prev 2015; 16(7):2959-2965.

19. Freitas-Junior R, Gonzaga CMR, Freitas NMA, Martins E, Dardes RCN. Disparities in female breast cancer mortality rates in Brazil between 1980 and 2009. Clinics 2012; 67(7):731-737.

20. Mendes KDS, Silveira RCCP, Galvão CM. Revisão integrativa: Método de pesquisa para a incorporação de evidencias na saúde e na enfermagem. Texto Contexto Enferm 2008; 17(4):758-764.

21. Amadou A, Fabre A, Torres-Mejía G, Ortega-Olvera C, Angeles-Llerenas A, McKenzie F, Biessy C, Hainaut P, Romieu I. Hormonal Therapy and Risk of Breast Cancer in Mexican Women. PLos ONE 2013; 8(11):e79695.

22. Matos JC, Pelloso SM, Carvalho MDB. Prevalence of Risk Factors for Breast Neoplasm in the City of Maringá, Paraná State, Brazil. Rev Latino-Am Enfermagem 2010; 18(3):352-359.

23. Rodríguez CC, Biset AED, Mayeta YB. Factores de riesgo de cáncer de mama en mujeres pertenecientes a um consultorio médico del Centro Urbano "José Martî". MEDISAN 2013; 17(9):4089-4095.

24. Banegas MP, Puschel K, Martínez-Gutiérrez J, Anderson JC, Thompson B. Perceived and Objective Breast Cancer Risk Assessment in Chilean Women Living in an Underserved Area. Cancer Epidemiol Biomarkers Prev 2012; 21(10):1716-1721.

25. Silva TB, Mauad EC, Carvalho AL, Jacobs LA, Shulman LN. Difficulties in implementing an organized screening program for breast cancer in Brazil with emphasis on diagnostic methods. Rural and Remote Health 2013; $13: 2321$

26. Schneider IJC, Corseuil MW, Boing AF, D'Orsi E. Knowledge about mammography and associated factors: population surveys with female adults and elderly. Rev Bras Epidemiol 2013; 16(4):930-942.

27. Batiston AP, Tamaki EM, Souza LA, Santos MLM. Conhecimento e prática sobre os fatores de risco para o câncer de mama entre mulheres de 40 a 69 anos. Rev. Bras. Saúde Matern Infant 2011; 11(2):163-171.

28. López-Carrillo L, Torres-Sánchez L, Blanco-Muñoz J, Hernández-Ramírez RU, Knaul FM. Utilización correcta de las técnicas de detección de cáncer de mama en mujeres mexicanas. Salud Pública de México 2014 56(5):538-546.
29. Ospina Díaz JM, Manrique Abril FG, Vega NA, Morales Pacheco AL, Ariza RNE. La no realización del autoexamen de mama en Tunja, Colombia. Enfermaría Global 2011; 10(3):30-40

30. Amadou A, Torres Mejía G, Fagherazzi G, Ortega C, Angeles-Llerenas A, Chajes V, Biessy C, Sighoko D, Hainaut P, Romieu I. Anthropometry, Silhouette Trajectory, and Risk of Breast Cancer in Mexican Women. Am J Prev Med 2014; 46(3Supl. 1):S52-S64.

31. Balderas-Peña LMA, Sat-Muñoz D, Cervantes JMC, Ramírez-Orozco RE, Ángeles-Bueno WG, FloresMárquez MR, Macías-López GG, Ruiz-Quezada SL, Salcedo-Rocha AL, Alba-García JEG, Solano-Murillo P. Porcentaje de adiposidad y su relación con el índice de inmunorreactividad de los receptores hormonales en mujeres mexicanas con cáncer de mama. Nutr Hosp 2013; 28(4):1321-1329.

32. Bering T, Mauricio SF, Silva JB, Correia MITD. Nutritional and metabolic status of breast cancer women. Nutr Hosp 2015; 31(2):751-758.

33. Matos JC, Pelloso SM, Carvalho MDB. Fatores associados à realização da prevenção secundária do câncer de mama no Município de Maringá, Paraná, Brasil. Cad Saude Publica 2011; 27(5):888-898.

34. Fejerman L, Romieu I, John EM, Lazcano-Ponce E, Huntsman S, Beckman KB, Pérez-Stable EJ, Burchard EG, Ziv E, Torres-Mejía G. European Ancestry Is Positively Associated with Breast Cancer Risk in Mexican Women. Cancer Epidemiol Biomarkers Prev 2010; 19(4):1074-1082.

35. Garmendia ML, Ruiz P, Uauy R. Obesidad y cáncer en Chile: estimación de las fracciones atribuibles poblacionales. Rev Med Chile 2013; 141(8):987-994.

36. Girianelli VR, Gamarra CJ, Silva GA. Disparities in cervical and breast cancer mortality in Brazil. Rev Saude Publica 2014; 48(3):459-467.

37. Inumaru LE, Quintanilha MIGD, Silveira EA, Naves MMV. Risk and Protective Factors for Breast Cancer in Midwest of Brazil. I Environ Public Health 2012; (2012):1-9.

38. Iwasaki M, Kasuga Y, Yokoyama S, Onuma H, Nishimura H, Kusama R, Hamada GS, Nishimoto IN, Maciel MS, Motola Júnior J, Laginha FM, Anzai R, Tsugane S. Comparison of postmenopausal endogenous sex hormones among Japanese, Japanese Brazilians, and non-Japanese Brazilians. BMC Medicine 2011; 9(16):1 11.

39. López-Carrillo L, Hernández-Ramírez RU, Calafat AM, Torres-Sánchez L, Galván-Portillo M, Needham LL, Ruiz-Ramos R, Cebrián ME. Exposure to Phthalates and Breast Cancer Risk in Northern Mexico. Environ Health Perspect 2010; 118(4):539-544.

40. Pereira A, Garmendia ML, Alvarado ME, Albala C. Hypertension and the Risk of Breast Cancer in Chilean Women: a Case-control Study. Asian Pacific J Cancer Prev 2012; 13(11):5829-5834.

41. Ronco AL, De Stefani E, Correa P, Deneo-Pellegrini H, Boffetta P, Acosta G, Mendilaharsu M. Dietary Benzo[a]pyrene, Alcohol Drinking, and Risk of Breast Cancer: a Case-control Study in Uruguay. Asian Pacific J Cancer Prev 2011; 12(6):1463-1467. 
42. Ronco AL, De Stefani E, Deneo-Pellegrini H, Quarneti A. Diabetes, Overweight and Risk of Postmenopausal Breast Cancer: A Case-Control Study in Uruguay. Asian Pacific J Cancer Prev 2012; 13(1):139-146.

43. Ronco AL, De Stefani E, Deneo-Pellegrini H. Risk Factors for Premenopausal Breast Cancer: A Case-control Study in Uruguay. Asian Pacific J Cancer Prev 2012; 13(6):2879-2886

44. De Stefani E, Moore M, Aune D, Deneo-Pellegrini H, Ronco AL, Boffetta P, Correa P, Acosta G, Mendilaharsu M, Luaces M, Silva C, Landó G. Maté Consumption and Risk of Cancer: a Multi-site Case- Control Study in Uruguay. Asian Pacific J Cancer Prev 2011; 12(4):10891093.

45. De Stefani E, Boffetta P, Ronco AL, Deneo-Pellegrini H, Correa P, Acosta G, Mendilaharsu G, Luaces ME, Silva C. Processed meat consumption and risk of cancer: a multisite case-control study in Uruguay. $\mathrm{Br} J$ Cancer 2012; 107(9):1584-1588.

46. Cordero MGA, Sánchez MN, López CAP, Ramírez MLP, Rillo AG, López AMS. Factores de riesgo como pronóstico de padecer cáncer de mama en un estado de México. Nutr Hosp 2012; 27(5):1631-1636.

47. Cabello G, Valenzuela-Estrada M, Siques P, Brito J, Parra E, Valdivia U, Lavin C, Manríquez A, Ortega A. Relation of Breast Cancer and Malathion Aerial Spraying in Arica, Chile. Int J Morphol 2013; 31(2):640-645.

48. Calderón-Garcidueñas AL, Sanabria-Mondragón M, Hernández-Beltrán L, López-Amador N, Cerda-Flores RM. Mammographic Breast Density Patterns in Asymptomatic Mexican Women. Radiology Research and Practice 2012; 2012:127485.

49. Ferri NN, Felice a Ferri A, Francisco a Ferri A, Brunicardi AH, Franco AT, Franco AM. Cáncer de mama e índice de masa corporal en mujeres posmenopáusicas. Rev Venez Oncol 2010; 22(2):94-102

50. Font-Gonzalez A, Piñeros M, Vries E. Self-reported early detection activities for breast cancer in Colombia in 2010: impact of socioeconomic and demographic characteristics. Salud Publica Mex 2013; 55:368-378.

51. Hernández D, Borges R, Márquez G, Betancourt L. Factores de riesgo conocidos para cáncer de mama. Rev Venez Oncol 2010; 22(1):16-31.

52. Grego MC, Ohara CVS, Pereira SR, Brêtas JRS. Workshop on breast self-examination: a strategy for selfknowledge of adolescents. Acta Paul Enferm 2011; 24(4):493-499.

53. Kim DD, Araujo ALL, Tsai AIA, Kojima FH, Takashima ISI, Otsuka Júnior LF, Gamboa RAB, Kimura R, Sugawara RT, Tambellini EF, Silveira C, Oliveira RLS. Saber é prevenir: uma nova abordagem no combate ao câncer de mama. Cien Saude Colet 2010; 15(1):1377-1381.

54. Hechavarría GAP, Cortés JTA, Capdesuñer AS, Selva OTG, Hechavarría ARP. Actividades educativas en mujeres com factores de riesgo de cáncer de mama. MEDISAN 2011; 15(6):754-761.

55. Sáez IH, Sáez YG, Benítez LYH, Cardoso AAH, Martín MC, Oliva SA. Intervención educativa sobre detección precoz del cáncer de mamas. Revista Archivo Médico Camaguey 2011; 15(3):487-503.
56. Guerrero GEM, Rodríguez YH, Martínez AMF. Acciones instructivas en mujeres con riesgo de padecer cáncer de mama. Revista Cubana de Obstetricia y Ginecología 2011; 37(4):541-550

57. Montañez SP, Alemán IR, Capdesuñer AS, Palácios MC. Modificación de conocimientos sobre cáncer de mama en trabajadoras com factores de riesgo de la enfermedad. MEDISAN 2011; 15(1):92-98.

58. Brito LMO, Chein MBC, Brito LGO, Amorim AMM, Marana HRC. Conhecimento, prática e atitude sobre o autoexame das mamas de mulheres de uma cidade do Nordeste do Brasil. Rev Bras Ginecol Obstet 2010; 32(5):241-246.

59. Curiel AT, Farías MV, Gutiérrez BLN, Carlos AAR, González ES, López JLL. Representación social que los adolescentes de Jalisco, México, tienen de la detección precoz del cáncer de Mama. Aten Primaria 2014; 46(8):408-415.

60. Silva NRA, Soares DA, Jesus SR. Conocimiento y práctica del autoexamen de mamas por usuarias de la Unidad de Salud de la Familia. Rev Enfermería Global 2013; 12(29):463-476.

61. Paci E, Broeders M, Hofvind S, Puliti D, Duffy SW. EUROSCREEN Working Group. European breast cancer service screening outcomes: a first balance sheet of the benefits and harms. Cancer Epidemiol Biomarkers Prev 2014; 23(7):1159-1163.

62. Pace LE, Keating NL. A systematic assessment of benefits and risks to guide breast cancer screening decisions. JAMA 2014; 311(13):1327-1335.

63. Jacobo-Galindoa T, Villalobos-Arámbulab L, Gallegos-Torresc R, Xeque-Moralesd AS, Reyes-Rochae B, Palomé-Vegaf G. Patrones de comportamiento para la detección de CA mamario em trabajadoras de una institución hospitalaria. Enfermería Universitaria 2014; 11(3):101-109.

64. Silva PA, Riul SS. Câncer de mama: fatores de risco e detecção precoce. Rev Bras Enferm 2011; 64(6):10161021.

65. Muñoz LM, Sánchez LC, Menes ML, Almaguer CC, López MCM. Valoración del conocimiento del autoexamen de mama en mujeres en edad reproductiva del Policlínico Bernardo Posse. Revista Habanera de Ciencias Médicas 2012; 11(3):361-368.

66. Gomes LMX, Alves MC, Santos TB, Andrade-Barbosa TL, Leite MTS. Conhecimento e prática do autoexame das mamas por acadêmicas de enfermagem. Revista Cubana de Enfermería 2012; 28(4):465-473.

67. Freitas CRP, Terra KL, Mercês NNA. Conhecimentos dos acadêmicos sobre prevenção do câncer de mama. Rev Gaúcha Enferm 2011; 32(4):682-687.

68. González JR, González AR, Torres AT, Taño RM. Conocimientos de los factores de riesgo sobre cáncer de mama en Puerto La Cruz, estado Anzoátegui, Venezuela. Revista Habanera de Ciencias Médicas 2012; 11(5):673-683.

69. Santos GD, Chubaci RYS. O conhecimento sobre o câncer de mama e a mamografia das mulheres idosas frequentadoras de centros de convivência em São Paulo (SP, Brasil). Cien Saude Colet 2011; 16(5):2533-2540.

Artigo apresentado em 27/05/2015

Aprovado em 22/10/2015

Versão final apresentada em 24/10/2015 